Article

\title{
Characterization of Two Novel Bacillus thuringiensis Cry8 Toxins Reveal Differential Specificity of Protoxins or Activated Toxins against Chrysomeloidea Coleopteran Superfamily
}

\author{
Changlong Shu ${ }^{1}$, Guixin Yan ${ }^{1}$, Shizhi Huang ${ }^{1}$, Yongxin Geng ${ }^{1}$, Mario Soberón ${ }^{2} \mathbb{D}$, \\ Alejandra Bravo ${ }^{2}$ (D), Lili Geng ${ }^{1}$ and Jie Zhang ${ }^{1, *}$ \\ 1 State Key Laboratory for Biology of Plant Diseases and Insect Pests, Institute of Plant Protection, \\ Chinese Academy of Agricultural Sciences, Beijing 100193, China; clshu@ippcaas.cn (C.S.); \\ yanguixin@caas.cn (G.Y.); simjue@126.com (S.H.); yongxin_Geng@hotmail.com (Y.G.); \\ llgeng@ippcaas.cn (L.G.) \\ 2 Instituto de Biotecnología, Universidad Nacional Autónoma de México, Cuernavaca 62250, Mexico; \\ mario@ibt.unam.mx (M.S.); bravo@ibt.unam.mx (A.B.) \\ * Correspondence: zhangjie05@caas.cn; Tel.: +86-10-62812642
}

Received: 14 September 2020; Accepted: 2 October 2020; Published: 5 October 2020

\begin{abstract}
Scarabaeoidea and Chrysomeloidea insects are agriculture-destructive coleopteran pests. Few effective Bacillus thuringiensis (Bt) insecticidal proteins against these species have been described. $\mathrm{Bt}$ isolate BtSU4 was found to be active against coleopteran insects. Genome sequencing revealed two new cry8 genes in BtSU4, designated as cry8Ha1 and cry8Ia1. Both genes expressed a $135 \mathrm{kDa}$ protoxin forming irregular shape crystals. Bioassays performed with Cry8Ha1 protoxin showed that it was toxic to both larvae and adult stages of Holotrichia parallela, also to Holotrichia oblita adults and to Anoplophora glabripennis larvae, but was not toxic to larval stages of $H$. oblita or Colaphellus bowringi. The Cry8Ia1 protoxin only showed toxicity against $H$. parallela larvae. After activation with chymotrypsin, the $\mathrm{Cry} 8 \mathrm{Ha} 1$ activated toxin lost its insecticidal activity against $\mathrm{H}$. oblita adults and reduced its activity on $H$. parallela adults, but gained toxicity against $C$. bowringi larvae, a Chrysomeloidea insect pest that feeds on crucifer crops. The chymotrypsin activated Cry8Ia1 toxin did not show toxicity to any one of these insects. These data show that Cry8Ha1 and Cry8Ia1 protoxin and activated toxin proteins have differential toxicity to diverse coleopteran species, and that protoxin is a more robust protein for the control of coleopteran insects.
\end{abstract}

Keywords: Bacillus thuringiensis; cry8 genes; Coleopteran; insecticidal activity; Cry protoxin; dual mode of action

Key Contribution: The study shows that Cry8Ha1 protein has a broad insecticidal spectrum against Chrysomeloidea and Scarabaeoidea pests.

\section{Introduction}

The Coleoptera (beetles) insect order contains more described species than any other animal group, with over 380,000 named species [1,2], comprising almost $40 \%$ of described insects and nearly $30 \%$ of all animal species. Among these beetles, the species from Scarabaeoidea and Chrysomeloidae superfamilies are considered as the most destructive coleopteran pests, which cause severe damages in agriculture, horticulture, and forestry. The insecticide formulations based on Bacillus thuringiensis (Bt) insecticidal proteins, as well as transgenic plants expressing Bt insecticidal proteins are applied as 
sustainable control methods for some species of these coleopteran pests [3,4]. However, comparing to the beetle's diversity, the currently discovered variability of Bt insecticidal proteins effective against coleopteran insects is scarce. Currently, only few members in Cry1, Cry3, Cry6 (now APP6), Cry7 Cry8, Cry22 (now XPP22), Cry23/Cry37 (now MPP23/XPP37), Cry34/Cry35 (now GPP34/TPP35), Cry55 (now XPP55), Cyt1, Cyt2, Sip (now MPP5), and Vip1/Vip2 subgroups of Bt protein families were reported to be toxic against certain coleopteran insects [5,6]. Hence, screening of Bt strains and identification of novel insecticidal proteins active against coleopteran insects, especially proteins that display a broad insecticidal spectrum against Chrysomeloidea and Scarabaeoidea is still needed for the effective control of these pests.

Bt insecticidal crystal proteins (ICPs) are synthetized as protoxins which, once ingested by the insect, are required to be solubilized, and proteolytically activated in the insect midgut [7,8]. The activated toxin binds to membrane receptors and lyses midgut epithelial cells by forming pores that cause cell swelling. Some of the Cry toxins with potential activity are only toxic after in vitro solubilization and activation with commercial proteases. For example, the toxicity of Cry7Aa towards coleopteran insect larvae was revealed only after an in vitro solubilization and activation with proteases [9]. For this reason, it is recommended to perform bioassays with both protoxins and activated toxins to detect insecticidal activity of a new Bt ICPs, especially against coleopteran larvae. In this report, we screened a new Bt strain, BtSU4, with insecticidal activity against Holotrichia parallela and we cloned two novel cry8-type genes from this strain. Furthermore, the expression, solubilization, activation and toxicity assays of the two novel ICPs indicated that the new Cry8Ha1 protein has a broad insecticidal spectrum important for the control of several important coleopteran pests.

\section{Results}

\subsection{Cloning and Sequence Analysis of cry8Ha1 and cry8Ia1 from BtSU4}

After BtSU4 genome sequencing and insecticidal gene annotation, two genes coding for proteins with similarity to Cry8 family were discovered. The two Cry8 proteins consisted of 1199 and 1194 amino acids, respectively. The two novel proteins were subsequently named as Cry8Ha1 and Cry8Ia1 (https://www.bpprc.org).

After CDD search, the core region of the two novel insecticidal proteins were identified. The domains I, II, and III of Cry8Ha1 protein were located from amino acids 94 to 290, 300 to 510 and 512 to 657, respectively. While for Cry8Ia1 protein these domain regions were located from amino acids 106 to 288, 296 to 516, and 517 to 665, respectively. BLAST analysis results showed that some domains of the two $\mathrm{Cry} 8 \mathrm{H}$ proteins have high similarity to other proteins from the Cry family such as Cry3, Cry1B, or Cry1I, rather than to Cry8 members.

Phylogenetic analysis were performed with the complete protoxin or the toxin core sequences of these two Cry8 proteins and compared with different Cry proteins (Figure 1). These analyses showed that protoxin sequences of $\mathrm{Cry} 8 \mathrm{Ha} 1$ and Cry8Ia1 clustered in a single branch with the other Cry 8 protoxins as expected. In contrast the sequence of the toxin cores of these proteins were found in different branches. The toxin core of $\mathrm{Cry} 8 \mathrm{Ha} 1$ toxin was found clustered in the same branch with Cry3 proteins together with Cry8Ba, Cry8Pa, Cry8Ca, and Cry8Ja, while Cry8Ia1 was found grouped with Cry8G, Cry8K, and Cry7G toxins (Figure 1). Suggesting that these two novel proteins Cry8Ha1 and Cry8Ia1 may have differential specificity.

We also performed phylogenetic analyses of the different domains. Analysis of domain I sequences from several Cry proteins showed that this region is distributed in three main clusters (Figure S1). Cluster A includes 11 different Cry8 proteins clustered with domain I sequences from Cry1B and Cry1I (Figure S1, Cluster A); the second group (Figure S1, Cluster B), includes domain I sequences from Cry8Ha1 and Cry8Ia1 that were found to be grouped with other nine Cry8 and Cry3 proteins; the third group (Figure S1, Cluster C) includes six members, forming a cluster including more distant Cry8 proteins (Figure S1). The sequences from domains II and III showed larger variation, where 
the Cry8Ha1 and Cry8Ia1 were located in different clusters. For domain II sequences six different clusters were identified, the Cry8Ha1 was located in Cluster A (Figure S2, Cluster A), which included sequences of domain II from Cry1B and Cry1I proteins, while Cry8Ia1 is found in cluster E with other Cry8 members such as Cry8Ib1, Cry8Ga1, Cry8Ka1, and Cry8Kb1 (Figure S2, Cluster E). Finally, for domain III sequences, they were classified in seven clusters, where the domain III of Cry8Ha1 is found in Cluster A, which includes sequences from Cry1I, Cry1B and Cry3 proteins (Figure S3, Cluster A), while Cry8Ia1 is found in Cluster E together with other Cry8 proteins, such as Cry8Ib1, Cry8Sa1, Cry8Ta,1 and Cry8La1 (Figure S3, Cluster E). These analyses show that Cry8Ha1 toxin is more closely related with Cry3, Cry1B, and Cry1I.
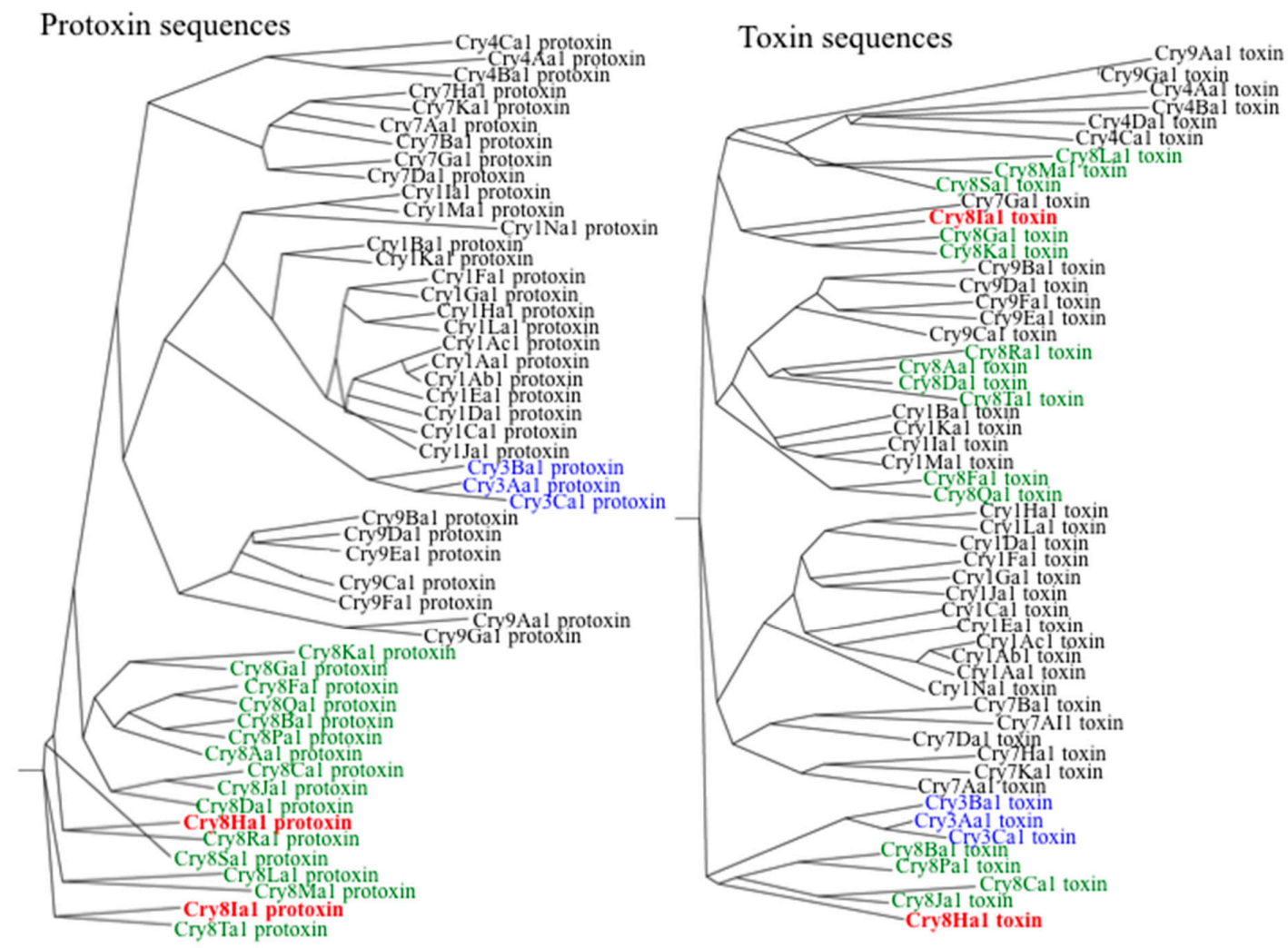

Figure 1. Phylogenetic analysis of the protoxin or toxin core amino acid sequences from different Cry proteins. These analyses involved 52 amino acid sequences. Evolutionary analyses were conducted in Clustal Omega and Neighbour-joining Phylogenetic analysis (Madeira et al. 2019). The Cry8Ha1 and Cry8Ia1 proteins were labeled in red letters.

\subsection{Differential Toxicity of Cry8Ha1 and Cry8Ia1 Protoxins and Activated Toxins Against Different Coleopteran Insects}

To express the cry8Ha1 and cry8Ia1 genes, primers were designed according to their gene sequences, amplified from the total DNA of BtSU4 strain and cloned into pSTK shuttle vector as described in Materials and Methods. The acrystalliferous HD-73- strain was transformed with these constructions by electroporation, and the resulted recombinant strains HD8H and HD8I were used to express these proteins and determine their toxicity against different coleopteran insects as described below. The morphology of the crystals produced by BtSU4, HD8H, and HD81 strains was analyzed in spore/crystal suspensions observed under scanning electron microscopy (SEM). Figure 2 shows that BtSU4 had typical Bt spores and relatively small irregular crystals (indicated by arrow). The ICPs accumulated in BtSU4 crystals were composed of $135 \mathrm{kDa}$ protein, as revealed by SDS-PAGE electrophoresis (Figure 2E). 

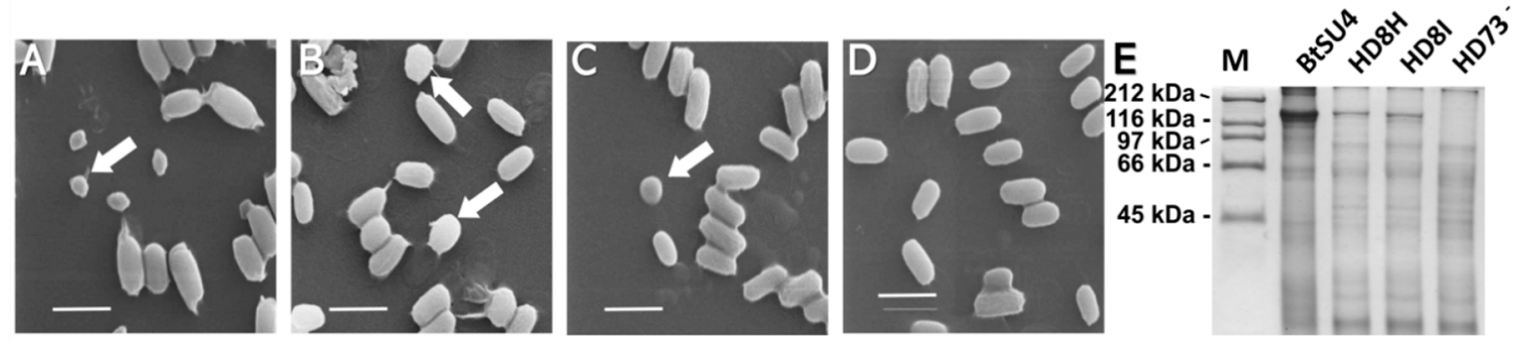

Figure 2. SEM observation and Electrophoretic analysis of Bt spore and crystal mixtures. Panels (A-D), SEM images of the spore and crystal mixtures of Bt strain BtSU4, HD8H, HD8I and crystal negative strain HD-73-. The scale bar in panels A, B, C and D was $2 \mu \mathrm{m}$. Panel (E), Sodium dodecyl sulfate-polyacrylamide gel electrophoresis (SDS-PAGE) profiles of these spore and crystal mixtures. M, Bio-Rad high-molecular-mass protein marker. The other lanes were total protein samples from Bt strain BtSU4, HD8H, HD8I and crystal negative strain HD-73-' respectively.

The SEM images of Figure 2 showed that both Cry8Ha1 and Cry8Ia1 crystals inclusions accumulated forming large irregular crystals (Figure 2B,C, indicated by arrows). SDS-PAGE analysis showed that the expressed Cry8Ha1 and Cry8Ia1 protoxins were resolved also as $135 \mathrm{kDa}$ bands (Figure 2E), similar to the ICPs molecular weight band observed for BtSU4 strain.

To compare the toxicity of protoxins with that of activated toxins of both Cry8Ha1 and Cry8Ia1 proteins, the protoxins of Cry8Ha1 and Cry8Ia1 were activated by chymotrypsin digestion. We decided to activate Cry8 toxins with chymotrypsin since it was previously shown that this protease was highly efficient for activation of Cry3Aa toxin that is toxic to coleopteran larvae in contrast to trypsin protease [10]. After digestion with chymotrypsin, the activated toxins were again analyzed by SDS-PAGE electrophoresis, showing that the Cry8Ha1 is activated into a $70 \mathrm{kDa}$ protein fragment after $2 \mathrm{~h}$ of treatment with the protease. The $70 \mathrm{kDa}$ protein fragment was relative stable since it remained after $24 \mathrm{~h}$ of treatment, although some of the $70 \mathrm{kDa}$ fragment was further degraded into a smaller fragment with a molecular weight about $55 \mathrm{kDa}$ (Figure 3). In contrast, the protoxin of Cry8Ia1 after protease treatment showed two main fragments of 97 and $66 \mathrm{kDa}$ (Figure 3).

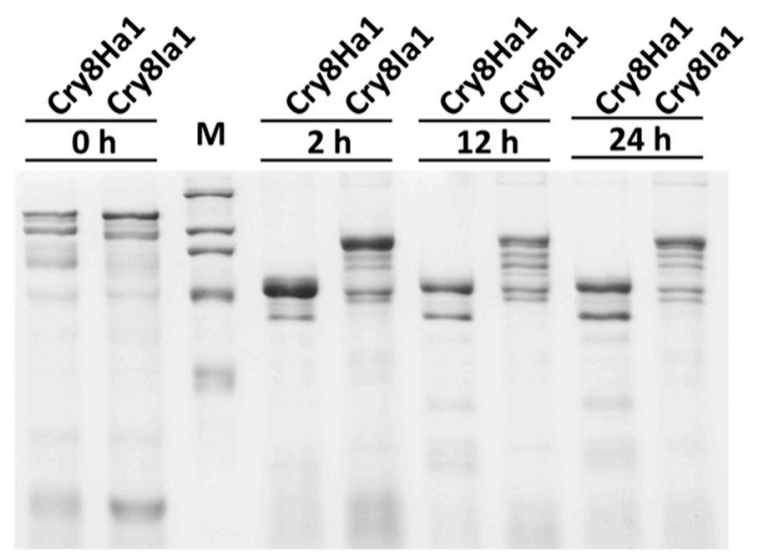

Figure 3. SDS-PAGE protein profile of Cry8Ha1 and Cry8Ia1 proteins, after digestion with chymotrypsin protease. " $\mathrm{M}$ " means the marker, and the molecular weight of the bands are 212, 116, 97, 66 and $45 \mathrm{kDa}$, respectively.

The toxicity of the two Cry8Ha1 and Cry8Ia1 protoxins was first analyzed against different insects (Table 1, Figure 4). The data showed that the Cry8Ha1 protoxin was toxic to both $H$. parallela larvae and adults. This protoxin was also toxic against $H$. oblita adults, but not to $H$. oblita larvae neither to C. bowringi larvae (Table 1). Analysis against A. glabripennis larvae showed that Cry8Ha1 protoxin was also toxic to the larvae of this insect (Figure 4). The Cry8Ha1 treated larvae showed a severe 
effect in their growth, they remain small, lack mobility and looks severely damaged, after few days of treatment they died. The image of Figure 4B shows these effects. In contrast, the Cry8Ia1 protoxin, showed toxicity only against $H$. parallela larvae and did not show toxicity to any the other insect tested in this study (Table 1). We then analyzed toxicity of the activated toxin samples, chymotrypsin activation caused the complete loss of toxicity of Cry8Ha1 to $H$. oblita adults and seems to reduce the activity against $H$. parallela adults when compared to the Cry8Ha1 protoxin, although these data are not significant since their fiducial limits overlapped. The activation of Cry8Ha1 toxin with chymotrypsin resulted in enhanced toxicity against C. bowringi larvae (Table 1). The activated Cry8Ia1 toxin showed no toxicity to any insects tested in this study.

Table 1. The $\mathrm{LC}_{50}$ Cry8Ha1 and Cry8Ia1 against Holotrichia oblita, Holotrichia parallela, and Colaphellus bowringi.

\begin{tabular}{|c|c|c|c|c|c|}
\hline \multirow{2}{*}{ Sample } & \multicolumn{2}{|c|}{ H. oblita } & \multicolumn{2}{|c|}{ H. parallela } & \multirow{2}{*}{$\begin{array}{c}\text { C. bowringi } \\
\text { Larvae } \\
\mathrm{LC}_{50} \text { Values in } \\
\mathrm{mg} / \mathrm{mL} \\
\text { (Confidence Limits) }\end{array}$} \\
\hline & $\begin{array}{c}\text { Adult } \\
\text { LC }_{50} \text { Values in } \\
\mathrm{mg} / \mathrm{mL} \\
\text { (Confidence Limits) }\end{array}$ & $\begin{array}{c}\text { Larvae } \\
10^{8} \mathrm{CFU} / \mathrm{g}\end{array}$ & $\begin{array}{c}\text { Adult } \\
\mathrm{LC}_{50} \text { Values in } \\
\mathrm{mg} / \mathrm{mL} \\
\text { (Confidence Limits) }\end{array}$ & $\begin{array}{c}\text { Larvae } \\
\text { LC }_{50} \text { Values in } 10^{8} \\
\text { CFU/g } \\
\text { (Confidence Limits) }\end{array}$ & \\
\hline Cry8Ha1-Pro & $0.99(0.62-2.05)$ & NA & $0.16(0.00-0.57)$ & $218.90(68.21-661.10)$ & NA \\
\hline Cry8Ia1-Pro & NA & NA & NA & $85.03(30.59-176.08)$ & NA \\
\hline Cry8Ha1-Act & NA & NT & $0.66(0.20-12.36)$ & NT & $0.02(0.01-0.02)$ \\
\hline Cry8Ia1-Act & NA & NT & NA & NT & NA \\
\hline
\end{tabular}

Note: the NA = no activity; NT = not tested; "-Pro" = protoxin; "-Act" = activated toxin; "CFU" = the colony-forming unit of crystal-spore mixture.

A

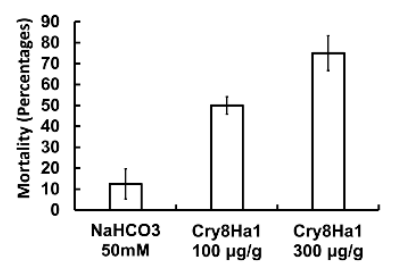

B

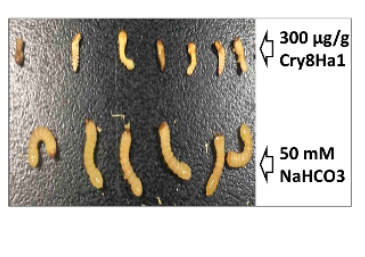

Figure 4. The bioassay of Cry8Ha1 protoxin against Anoplophora glabripennis. (A): the mortality of A. glabripennis treated by different dose of $\mathrm{Cry} 8 \mathrm{Ha} 1$ protoxin. This experimented was performed in triplicate. For each repeat, 24 larvae were tested; (B): Morphology of toxin-treated A. glabripennis larvae.

\section{Discussion}

The Cry8 toxin family has been reported to have toxicity against coleopteran insects and until now 60 different Cry8 proteins (including 2 Cry8-like proteins) that belong to 28 holotypes by the new Bacterial Pesticidal Protein Resource Center (BPPRC) (https://www.bpprc.org) [6]. Cry8 proteins have been shown to be mainly toxic to Scarabs, but some patents claimed that certain Cry8 proteins also show toxicity to Chrysomeloidea insects [11]. The larvae and adults of both Scarabs and Chrysomeloidea insects feed on plants, thus it is important to find effective strategies to control both stages of these insects. Until recently, as shown in Figure 5, the Cry8Ab, Cry8Ca, Cry8Da, Cry8Db, Cry8Ea, Cry8Ga, Cry8Na, and a Cry8-like protein have been confirmed toxic to six main harmful scarabs. Among these proteins, the Cry8Da, Cry8Db and Cry8Ga proteins have shown to be effective against both adults and larvae stages of the insects [12,13]. In this study, we show that the protoxin from the novel Cry8Ha1 showed toxicity against both adults and larvae of $H$. parallela. In contrast, this Cry8Ha1 protoxin was only toxic to the adults of $H$. oblita, but not to the larvae. In addition, Cry8Ha1 was toxic to the larvae of A. glabripennis. The protoxin of the new Cry8Ia1 was only toxic to the larval stages of H. parallela. The reason for the differential toxicities of these protoxins observed in adults or larvae stages of certain species is not known, but one alternative could be related to a differential expression of Cry 8 midgut receptors in both developmental stages. This hypothesis remains to be analyzed. 
The phylogenetic analysis of Cry8Ha toxin core sequence showed that this proteins is more related to Cry3 proteins and the analysis of the different domains of Cry8Ha1 and Cry8Ia1 proteins confirmed that Cry8Ha1 is more related to the coleopteran active proteins Cry3, Cry1B, and Cry1I that have been shown to be specifically toxic to Chrysomeloidea insects [5]. Our data suggest that the novel Cry8Ha1 and Cry8Ia1 proteins have evolved from different origins, since these Cry8Ha1 and Cry8Ia1 proteins do not cluster together. Only Domain I of both Cry8Ha1 and Cry8Ia1 proteins clustered together with domain I from Cry3 proteins. Domain II of Cry8Ha1 is more related to domain II from Cry1B and Cry1I proteins; while Domain III of this protein is closer to domain III from the Cry1B, Cry1I, and Cry3 coleopteran active proteins. In contrast Domains II and III of Cry8Ia1 are not related to the corresponding domains of other coleopteran active toxins, only to other Cry8 proteins, such as Cry8Ib and Cry8Ga. Based in these close phylogenetic relationships with other Cry toxins active against Chrysomeloidea insects we decided to determine the toxicity of the two novel Cry8Ha1 and Cry8Ia1 proteins against some Chrysomeloidea pests, such as C. bowringi and A. glabripennis. For C. bowringi, Cry8Ha1 was effective, but the toxicity was revealed only with the Cry8Ha1 activated toxin after in vitro activation. Previously, a similar observation was made with the Cry7Aa1 protein against Colorado potato beetle where only the in vitro activated Cry7Aa1 protein showed to be toxic [9]. It has been shown that the content of midgut proteases may have great variations between different insects orders, for example, the main digestive proteases of Lepidoptera and Diptera are serine proteases, whereas those of Coleoptera are mainly cysteine and aspartic proteases [14]. Therefore, it is possible that the Cry8Ha1 is not processed correctly by the $C$. bowringi midgut proteases but the in vitro processing could activate the toxin properly revealing its toxicity against $C$. bowring $i$ larvae. In the case of $A$. glabripennis, the Cry8Ha1 protoxin was effective against $A$. glabripennis larvae, which is a Cerambycidae insect that harms many forests plants. Until recently, only Cry3Aa protein was shown to has toxicity to some Cerambycidae species, including Phytoecia rufiventris Gautier, Apriona germari, as well as A. glabripennis [15-17]. The discovering of new insecticidal proteins with different amino acid sequences that may have different modes of action is important to have additional tools for the control of Cerambycidae and Chrysomeloidea insects. The toxicity of Cry8Ha1 to two different Cerambycidae and Chrysomeloidea species suggests that other Cry8 proteins could also potentially show toxicity to different coleopteran species.

In addition, we also find that the in vitro solubilization and activation was adverse for Cry8Ha1 activity to scarab adults and also for its toxicity against the larval stages of $H$. parallela, since a reduction in toxicity was observed with the activated toxin. These data could indicate that the treatment with chymotrypsin inactivates the Cry8Ha1 protoxin or that two different mechanisms exist for protoxin or activated toxin, as previously suggested [15]. The fact that Cry8Ha1 activated toxins increases is toxic effect against $C$. bowringi larvae indicates that chymotrypsin treatment did not inactivate Cry8Ha1. Rather, the data indicate that both $\mathrm{Cry} 8 \mathrm{Ha} 1$ protoxin and activated toxin may have independent toxicity pathways in the different insect species analyzed. In the case of Cry1 Ab and Cry1Ac toxins, it has been shown that protoxins and activated toxins exert toxicity by independent pathways, where two different oligomer prepores with different pore formation activity are formed depending if protoxin or activated toxin bind to cadherin receptor [18]. Furthermore, it has been shown that the C-terminal region of Cry1 Ab protoxin provides additional binding sites for alkaline phosphatase (ALP) and aminopeptidase $\mathrm{N}(\mathrm{APN})$ receptors providing a higher binding affinity of the protoxin to the gut membrane which contributes to the higher toxicity of $\mathrm{Cry} 1 \mathrm{Ab}$ protoxin compared to the activated toxin [19]. It remains to identify the different protoxin or activated Cry8Ha1 binding proteins in the different insects analyzed and in the different developmental stages. However, an alternative explanation could be that the differential toxicity observed between Cry8Ha1 protoxin or activated toxin is related to the differential proteases that are present in the different insects analyzed. In any case, our data point out that the differential toxicities of protoxin or activated toxin should be taken into account to decide which form of the toxin should be expressed in transgenic plants, depending on the target pest. 


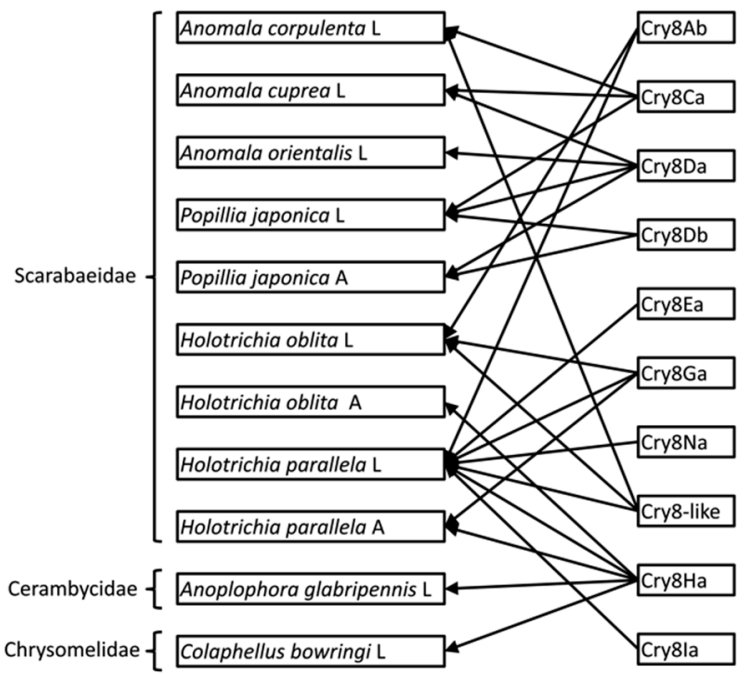

Figure 5. Insecticidal activity data of Cry8 proteins published before and in this work [12,20-26]. The "A" and " $\mathrm{L}$ " labels after the insect name means the "Adult" or "Larvae" stages of those insects.

\section{Conclusions}

In this paper, we characterized two new insecticidal proteins, Cry8Ha1 and Cry8Ia1. In addition to the larvicidal activity against $H$. parallela, the Cry8Ha1 showed to be toxic to the adults of $H$. parallela and H. oblita, and to the larvae of some Cerambycidae insects such as C. bowringi and A. glabripennis. Considering the sequence cluster characterization and the insecticidal spectrum of Cry8Ha1, this study not only provides new tools to control coleopteran insects, but also a valuable material for the ongoing investigation of insecticidal specific evolution, as well as potential strategies for further toxin improvements.

\section{Materials and Methods}

\subsection{Bacteria Growth Conditions and Plasmids}

The BtSU4 strain used in this study was isolated from soil samples in Hebei province, China. HD-73- a crystal negative Bt strain, was used as recipient strain for the expression of the novel Cry8 proteins. Bt strains were incubated for 3 days in cross-baffled flasks at $30^{\circ} \mathrm{C}$ with shaking at $230 \mathrm{rpm}$ in PB medium ( $0.5 \%$ peptone, $0.3 \%$ beef extract; $\mathrm{pH} 7.2$ ) for expressing the cry8 genes. Escherichia coli DH5 $\alpha$ strain was used for common transformation, while E. coli SCS110 strain was used to produce nonmethylated plasmid DNA for Bt transformation. The E. coli strains were grown at $37{ }^{\circ} \mathrm{C}$ in Luria-Bertani medium (LB: $1 \%$ tryptone, $0.5 \%$ yeast extract, $1 \% \mathrm{NaCl} ; \mathrm{pH} 7.0$ ). Plasmids derivative from pSTK [27] were constructed for cloning and expression of the genes. Kanamycin $\left(50 \mu \mathrm{g} \mathrm{mL}^{-1}\right)$ was added to the media, when appropriate, for selection of E. coli and Bt antibiotic resistant strains.

\subsection{Gene Cloning and Sequence Analysis}

In order to clone ICPs genes from BtSU4 strain, the Roche/454 technology was used to sequence the complete genome of this strain. After genome assembling, performed by Roche 454's Newbler, the contig00204 (GenBank accession number MT905434) was detected, containing two ICPs genes by using the Basic Local Alignment Search Tool (BLAST, https:/ftp.ncbi.nlm.nih.gov/blast/executables/ blast+) and an in-house Bt toxin genes database. The two cry-type genes were deposited in GenBank with the following accession numbers AY897354 and EU381044. The new Cry proteins were annotated by using the Conserved Domains Database (CDD) search (https://www.ncbi.nlm.nih.gov/cdd/). The Phylogenetic analyses of the amino acid sequences were conducted by Neighbour-joining [28] and MEGA X [29]. 


\subsection{Protein Expression, Extraction and Activation}

Primers were designed to clone the novel ICPs genes. SU4_5 (5'-GGA ATT CGA TGA GTC CGA ATA ATC AGA AT-3') and 8H_3 (5'-CGC GTC GAC TTA CAT TTC TTC TAC AAT CAA TTC-3') primers were designed to amplify cry8Ha1 gene, while SU4_5 and 8I_3 (5'-CTC ATT TCT TCT ACA ATC AAT TCT ACA CTG TC-3') primers were used to amplify cry8Ia1 gene. A KOD DNA polymerase and PTC-100 Peltier Thermal Cycler (MJ Research) was used for PCR, comprising 30 cycles (each cycle was composed of $1 \mathrm{~min}$ at $94{ }^{\circ} \mathrm{C}, 1 \mathrm{~min}$ at $54{ }^{\circ} \mathrm{C}$, and $4 \mathrm{~min}$ at $68^{\circ} \mathrm{C}$ ) followed by 10 min incubation at $68^{\circ} \mathrm{C}$. The amplified full-length cry8Ha1 and cry8Ia1 genes were inserted into the EcoRI-SalI sites and EcoRI-EcoICRI sites of the pSTK shuttle vector, respectively. The plasmids purified from E. coli DH5 $\alpha$ strain were then transformed into E. coli SCS110 for producing nonmethylated recombinant plasmids. Then, the expression vectors containing cry8Ha1 and cry8Ia1 genes were introduced into the crystal negative Bt strain HD-73- by electroporation [27]. The positive transformant colonies were incubated in LB medium supplemented with kanamycin at $30{ }^{\circ} \mathrm{C}$ until sporulation. The spore/crystal mixtures were collected and washed twice in $1.0 \mathrm{M} \mathrm{NaCl}$ and sterile distilled water successively. The final suspension was analyzed by sodium dodecyl sulfate-polyacrylamide gel electrophoresis (SDS-PAGE) $10 \%$ acrylamide gel.

The crystal/spore mixtures were subsequently solubilized in a $\mathrm{pH} 10.2$ buffer containing $50 \mathrm{mM}$ $\mathrm{Na}_{2} \mathrm{CO}_{3}, 50 \mathrm{mM}$ EDTA, 3\% 2-mercaptoethanol, incubated on a rotary shaker at $150 \mathrm{rpm}$ at $0{ }^{\circ} \mathrm{C}$ for $4 \mathrm{~h}$. The supernatant soluble protoxins were separated by centrifugation at $13,500 \times g$ for $10 \mathrm{~min}$ and the protoxins were precipitated by adding $4 \mathrm{M}$ Sodium acetate-Acetic acid (NaAc-HAc) buffer ( $\mathrm{pH} 4.5$ ) until the $\mathrm{pH}$ reached 5.0 and then incubated at $4{ }^{\circ} \mathrm{C}$ for $4 \mathrm{~h}$. The protoxin pellet was collected by centrifugation at $13,500 \times g$ and washed with pre-chilled distilled water three times to remove NaAc and $\mathrm{HAc}$, and then dissolved in $50 \mathrm{mM} \mathrm{Na}_{2} \mathrm{CO}_{3}$ ( $\mathrm{pH}$ 10.2). The protoxins were activated by treatment with chymotrypsin (Sigma) (10:1 w/w). The digestion was carried out in $50 \mathrm{mM} \mathrm{Na}_{2} \mathrm{CO}_{3}$ buffer ( $\left.\mathrm{pH} 10.2\right)$ at $37^{\circ} \mathrm{C}$ for 2,12 or $24 \mathrm{~h}$. Reactions were stopped by chilling in ice. The digested proteins were then boiled 3 min with protein-loading dye and analyzed on a 10\% acrylamide SDS-PAGE.

\subsection{Scanning Electron Microscopy (SEM) Examination}

After sporulation in LB medium, Bt spores and crystals were harvested by centrifugation at $13,500 \times g$ for $1 \mathrm{~min}$. The pellets were suspended and washed twice in distilled water. SEM micrographs were taken according to the method described before [27]. The suspension was smear on glass slide and placed on aluminum stubs, dried, and fixed in $1 \% \mathrm{OsO} 4$. Then, the spore crystal mixtures were sputter-coated with gold in an IB-5 ion coater (EIKO Engineering) for $4 \mathrm{~min}$. The SEM micrographs were taken on a Hitachi S4800 digital scanning microscope (Hitachi High-Tech, Japan) at a voltage of $12 \mathrm{kV}$

\subsection{Insects, Rearing Conditions and Bioassay}

Adults of $H$. oblita and H. parallela were collected from Baoding and Cangzhou, Hebei province, China. These adults were reared in plastic boxes filled with $5 \mathrm{~cm}$ thick sieved soil and fed with elm (Ulmus pumila L.) leaves, at $25 \pm 0.5^{\circ} \mathrm{C}, 16 \mathrm{~L}$ : $8 \mathrm{D}$ photoperiod condition and $60 \%$ humidity. The eggs were collected and hatched in the same conditions.

For bioassay activity against adults, we used the leaf-dipping method. Before feeding, the cleaned elm leaves were soaked in Cry protoxin protein solutions, and then the surface liquid was dried at room temperature. In each treatment, ten adults were feed with the dipped leaves, and then, we replaced the protein dipped elm leaves and check insect mortality every day. These assays were done in triplicate for each protein concentration, using a two-fold dilution protein concentration series $(0.03125 \mathrm{mg} / \mathrm{mL}$, $0.0625 \mathrm{mg} / \mathrm{mL}, 0.125 \mathrm{mg} / \mathrm{mL}, 0.25 \mathrm{mg} / \mathrm{mL}, 0.5 \mathrm{mg} / \mathrm{mL}, 1.0 \mathrm{mg} / \mathrm{mL}$, and $2.0 \mathrm{mg} / \mathrm{mL}$ ). For bioassays against larvae, we used a procedure modified from Shu (2009) [20]. Five-day larvae were feed with a mixture of potato with spores/crystal suspension. Firstly, the potato was shred, washed, air dried 
and then mixed with Bt spore/crystal water suspension; then, the mixture was further mixed with sieved soil and divide evenly into four six-well culture plates. In each treatment, 24 larvae were feed separately in each well performed in triplicate and mortality was determined after 14 day.

The adults of $A$. glabripennis were collected from Beijing, China, and reared in plastic boxes filled with pieces of willow branches (Salix babylonica), at $25 \pm 0.5{ }^{\circ} \mathrm{C}, 16 \mathrm{~L}$ : $8 \mathrm{D}$ photoperiod condition, $60 \%$ humidity. The adults feed on the bark and lay their eggs in the bark. The eggs hatch and larvae bioassay were performed on artificial diet. To prepare the artificial diet, we made willow bark powder and willow xylem powder. Branches with a diameter of 5-6 cm from the growing willow were used to separate the willow bark and xylem. Then, we washed, dried, ground, and sieved (80 meshes) the bark and xylem, respectively. The resulted powders were ready for use. The artificial diet was produced by mixing $60 \mathrm{~g}$ willow bark powder, $30 \mathrm{~g}$ willow xylem powder, $22.5 \mathrm{~g}$ agar, $10 \mathrm{~g}$ yeast powder, $1.5 \mathrm{~g}$ sorbic acid, $1.5 \mathrm{~g}$ methyl 4-hydroxybenzoate, $1.5 \mathrm{~g}$ ascorbic acid, and $520 \mathrm{~mL}$ sterile water, and sterilized at $121{ }^{\circ} \mathrm{C}$ for $20 \mathrm{~min}$. To perform bioassays, the Cry proteins were mixed with the artificial diet and divided into a 24-well culture plates, with final protein concentrations of $100 \mu \mathrm{g} / \mathrm{g}$, and $300 \mu \mathrm{g} / \mathrm{g}$; then, 24 two-day larvae were feed separately in each well in triplicate in a dark condition, and mortality was determined after 10 days.

The C. bowringi Baly population was reared in the lab using rape leaves. The bioassays were performed in triplicate against larvae by using the leaf dipping method. Before feeding, the cleaned rape leaves were soaked in Cry protein solutions with two-fold dilution series of protein concentrations of $0.125 \mu \mathrm{g} / \mathrm{mL}, 0.0625 \mu \mathrm{g} / \mathrm{mL}, 0.03125 \mu \mathrm{g} / \mathrm{mL}, 0.01563 \mu \mathrm{g} / \mathrm{mL}$, and $0.007815 \mu \mathrm{g} / \mathrm{mL}$, and then the surface liquid was dried at room temperature. In each treatment, 20 larvae were feed with the dipped leaves, at $25 \pm 0.5^{\circ} \mathrm{C}, 16 \mathrm{~L}$ : $8 \mathrm{D}$ photoperiod, $60 \%$ humidity, the mortality was determined after two days.

As mentioned above three replicates were performed for each treatment for all bioassays. The $50 \%$ lethal concentrations $\left(\mathrm{LC}_{50}\right)$ were determined by Probit analysis. For all leaf dipping method, 0.005\% Triton X-100 was added to increase fluid ductility and allowing uniform protein dip.

Supplementary Materials: The following are available online at http:/www.mdpi.com/2072-6651/12/10/642/s1. Figure S1. UPGMA phylogenetic analysis of the amino acid sequences from domain I of Cry proteins, Figure S2. UPGMA phylogenetic analysis of the amino acid sequences from domain II of Cry proteins, Figure S3. UPGMA phylogenetic trees of the amino acid sequences from domain III of Cry proteins.

Author Contributions: C.S. and J.Z. conceived and designed the experiments; C.S., G.Y., S.H. and Y.G. performed the experiments; M.S., A.B. and L.G. analyzed the data; J.Z. contributed materials and analysis tools; C.S., M.S. and A.B. wrote the paper. All authors have read and agreed to the published version of the manuscript.

Funding: This study was supported by the National Key Research and Development Program of China 2017YFD0201204 and National Natural Science Foundation of China No. 31872935.

Conflicts of Interest: The authors declared that they have no conflicts of interest to this work.

\section{References}

1. Bouchard, P.; Bousquet, Y. Additions and corrections to "Family-group names in Coleoptera (Insecta)". ZooKeys 2020, 922, 65-139. [CrossRef] [PubMed]

2. Bouchard, P.; Bousquet, Y.; Davies, A.E.; Alonso-Zarazaga, M.A.; Lawrence, J.F.; Lyal, C.H.; Newton, A.F.; Reid, C.A.; Schmitt, M.; Slipiński, S.A.; et al. Family-group names in Coleoptera (Insecta). ZooKeys 2011, 88, 1-972. [CrossRef] [PubMed]

3. Bravo, A.; Likitvivatanavong, S.; Gill, S.S.; Soberón, M. Bacillus thuringiensis: A story of a successful bioinsecticide. Insect Biochem. Mol. Biol. 2011, 41, 423-431. [CrossRef] [PubMed]

4. Kumar, S.; Chandra, A.; Pandey, K.C. Bacillus thuringiensis (Bt) transgenic crop: An environment friendly insect-pest management strategy. J. Environ. Biol. 2008, 29, 641-653. [PubMed]

5. Wang, K.; Shu, C.; Zhang, J. Effective bacterial insecticidal proteins against coleopteran pests: A review. Arch. Insect Biochem. Physiol. 2019, 102, e21558. [CrossRef]

6. Crickmore, N.; Berry, C.; Panneerselvam, S.; Mishra, R.; Connor, T.R.; Bonning, B.C. A structure-based nomenclature for Bacillus thuringiensis and other bacteria-derived pesticidal proteins. J.Invertebr. Pathol. 2020, 107438. [CrossRef] 
7. Heckel, D.G. How do toxins from Bacillus thuringiensis kill insects? An evolutionary perspective. Arch. Insect Biochem. Physiol. 2020, 104, e21673. [CrossRef]

8. Pardo-López, L.; Soberón, M.; Bravo, A. Bacillus thuringiensis insecticidal three-domain Cry toxins: Mode of action, insect resistance and consequences for crop protection. FEMS Microbiol. Rev. 2013, 37, 3-22. [CrossRef]

9. Lambert, B.; Höfte, H.; Annys, K.; Jansens, S.; Soetaert, P.; Peferoen, M. Novel Bacillus thuringiensis insecticidal crystal protein with a silent activity against coleopteran larvae. Appl. Environ. Microbiol. 1992, 58, 2536-2542. [CrossRef]

10. Carroll, J.; Convents, D.; Van Damme, J.; Boets, A.; Van Rie, J.; Ellar, D.J. Intramolecular proteolytic cleavage of Bacillus thuringiensis Cry3A delta-endotoxin may facilitate its coleopteran toxicity. J. Invertebr. Pathol. 1997, 70, 41-49. [CrossRef]

11. Hey, T.D.; Larrinua, I.M.; Narva, K.E. Modified Bacillus thuringiensis cry proteins that inhibit coleopterans. US Patent No. 8,269,069, 18 September 2012.

12. Yamaguchi, T.; Sahara, K.; Bando, H.; Asano, S. Discovery of a novel Bacillus thuringiensis Cry8D protein and the unique toxicity of the Cry8D-class proteins against scarab beetles. J. Invertebr. Pathol. 2008, 99, 257-262. [CrossRef] [PubMed]

13. Shizhi, H.; Changlong, S.; Chunqin, L.; Xuezhi, D.; Jie, Z. Screening of Insecticidal Activity Protein against Holotrichia parallela Adults from Bacillus thuringiensis. Chin. J. Biol. Control 2018, 34, 546-552.

14. Terra, W.R.; Ferreira, C. Insect digestive enzymes: Properties, compartmentalization and function. Compbiochemphysiol B 1994, 109, 1-62. [CrossRef]

15. Zhou, Z.; Yin, X.M.; Meng-Zhu, L.U.; Jiang, Z.W.; Wang, P. mBt886cry3a Gene Transformed into Chrysanthemum Dendranthemum grandiflorum 'Xiao Huang' Resistant to The Long Horn Beetles. North. Hortic. 2009, 11, 48-50.

16. Chen, J.; Dai, L.Y.; Wang, X.-P.; Tian, Y.C.; Lu, M. The cry3Aa gene of Bacillus thuringiensis Bt886 encodes a toxin against long-horned beetles. Appl. Microbiol. Biotechnol. 2005, 67, 351-356. [CrossRef]

17. Guo, C.H.; Zhao, S.T.; Ma, Y.; Hu, J.J.; Han, X.J.; Chen, J.; Lu, M.Z. Bacillus thuringiensisCry3Aa fused to a cellulase-binding peptide shows increased toxicity against the longhorned beetle. Appl. Microbiol. Biotechnol. 2012, 93, 1249-1256. [CrossRef]

18. Tabashnik, B.E.; Zhang, M.; Fabrick, J.A.; Wu, Y.; Gao, M.; Huang, F.; Wei, J.; Zhang, J.; Yelich, A.; Unnithan, G.C.; et al. Dual mode of action of Bt proteins: Protoxin efficacy against resistant insects. Sci. Rep. 2015, 5, 15107. [CrossRef]

19. Peña-Cardeña, A.; Grande, R.; Sánchez, J.; Tabashnik, B.E.; Bravo, A.; Soberón, M.; Gómez, I. The C-terminal protoxin region of Bacillus thuringiensis Cry1 Ab toxin has a functional role in binding to GPI-anchored receptors in the insect midgut. J. Biol. Chem. 2018, 293, 20263-20272. [CrossRef]

20. Shu, C.; Yan, G.; Wang, R.; Zhang, J.; Feng, S.; Huang, D.; Song, F. Characterization of a novel cry8 gene specific to Melolonthidae pests: Holotrichia oblita and Holotrichia parallela. Appl. Microbiol. Biotechnol. 2009, 84, 701-707. [CrossRef]

21. Zhang, Y.; Zheng, G.; Tan, J.; Li, C.; Cheng, L. Cloning and characterization of a novel cry8Ab1 gene from Bacillus thuringiensis strain B-JJX with specific toxicity to scarabaeid (Coleoptera: Scarabaeidae) larvae. Microbiol. Res. 2013, 168, 512-517. [CrossRef]

22. Shu, C.; Yu, H.; Wang, R.; Fen, S.; Su, X.; Huang, D.; Zhang, J.; Song, F. Characterization of two novel cry8 genes from Bacillus thuringiensis strain BT185. Curr. Microbiol. 2009, 58, 389-392. [CrossRef] [PubMed]

23. Li, H.; Liu, R.; Shu, C.; Zhang, Q.; Zhao, S.; Shao, G.; Zhang, X.; Gao, J. Characterization of one novel cry8 gene from Bacillus thuringiensis strain Q52-7. World J. Microbiol. Biotechnol. 2014, 30, 3075-3080. [CrossRef]

24. Sato, R.; Takeuchi, K.; Ogiwara, K.; Minami, M.; Kaji, Y.; Suzuki, N.; Hori, H.; Asano, S.; Ohba, M.; Iwahana, H. Cloning, heterologous expression, and localization of a novel crystal protein gene from Bacillus thuringiensis serovar japonensis strain buibui toxic to scarabaeid insects. Curr. Microbiol. 1994, 28, 15-19. [CrossRef] [PubMed]

25. Shu, C.; Liu, R.; Wang, R.; Zhang, J.; Feng, S.; Huang, D.; Song, F. Improving toxicity of Bacillus thuringiensis strain contains the cry8Ca gene specific to Anomala corpulenta larvae. Curr. Microbiol. 2007, 55, 492-496. [CrossRef] [PubMed] 
26. Asano, S.; Yamashita, C.; Iizuka, T.; Takeuchi, K.; Yamanaka, S.; Cerf, D.; Yamamoto, T. A strain of Bacillus thuringiensis subsp. galleriae containing a novel cry8 gene highly toxic to Anomala cuprea (Coleoptera: Scarabaeidae). Biol. Control 2003, 28, 191-196. [CrossRef]

27. Wang, G.; Zhang, J.; Song, F.; Wu, J.; Feng, S.; Huang, D. Engineered Bacillus thuringiensis GO33A with broad insecticidal activity against lepidopteran and coleopteran pests. Appl. Microbiol. Biotechnol. 2006, 72, 924-930. [CrossRef]

28. Madeira, F.; Park, Y.; Lee, J.; Buso, N.; Gur, T.; Madhusoodanan, N.; Basutkar, P.; Tivey, A.R.N.; Potter, S.C.; Finn, R.D.; et al. The EMBL-EBI search and sequence analysis tools APIs in 2019. Nucleic Acids Res. 2019, 47, W636-W641. [CrossRef]

29. Kumar, S.; Stecher, G.; Li, M.; Knyaz, C.; Tamura, K. MEGA X: Molecular Evolutionary Genetics Analysis across Computing Platforms. Mol. Boil. Evol. 2018, 35, 1547-1549. [CrossRef]

C 2020 by the authors. Licensee MDPI, Basel, Switzerland. This article is an open access article distributed under the terms and conditions of the Creative Commons Attribution (CC BY) license (http://creativecommons.org/licenses/by/4.0/). 